\title{
Combination of air stripping and biological processes for landfill leachate treatment
}

\author{
Yosr Smaoui $^{1^{\dagger}}$, Jalel Bouzid ${ }^{1}$, Sami Sayadi ${ }^{2}$ \\ ${ }^{1}$ Laboratory of Environmental Engineering and Eco Technology, National School of Engineers of Sfax, University of Sfax, BPW, 3038, Sfax, Tunisia \\ ${ }^{2}$ Environmental Bioprocesses Laboratory, LMI Cosys-Med, Centre of Biotechnology of Sfax, BP: «1177», 3018 Sfax, Tunisia
}

\begin{abstract}
Landfill waste decomposition generates a dark effluent named, leachate which is characterized by high organic matter content. To minimize these polluting effects, it becomes necessary to develop an effective landfill leachate treatment process. The objective of this study was to evaluate the performance of an innovative approach based on air stripping, anaerobic digestion (AD) and aerobic activated sludge treatment. A reduction of $80 \%$ of ammonia and an increase of carbon to nitrogen ratio to 25 were obtained, which is a suitable ratio for $\mathrm{AD}$. This latter $\mathrm{AD}$ was performed in fixed bed reactor with progressive loading rate that reached 2 and $3.2 \mathrm{~g} \mathrm{COD} / \mathrm{L} / \mathrm{d}$ for the raw and diluted leachate (1:2), respectively. The anaerobic treatment led to significant removal of chemical oxygen demand (COD) and biogas production, especially for the diluted leachate. The COD removal was of $78 \%$ for the raw leachate and a biogas production of $4 \mathrm{~L} / \mathrm{d}$ with $70 \%$ methane content. The use of the diluted leachate led to $81 \%$ of COD removal and $7 \mathrm{~L} / \mathrm{d}$ biogas with $75 \%$ methane content. It allowed a removal of $77 \%$ COD and more than $97 \%$ of the organic compounds present in the initial leachate sample.
\end{abstract}

Keywords: Activated sludge, Air stripping, Anaerobic digestion, GC-MS, Landfill leachate, Methane production

\section{Introduction}

Landfill leachate (LFL) is dark effluent resulting from waste decomposition. It contains high amounts of organic matter [1], recalcitrant compounds [2] and emerging contaminants [3]. If it is not properly collected and treated, it may cause a critical environmental problem to groundwater [4]. An effective LFL treatment process is then required to minimize these threats. LFL constitutes one of the most challenging wastewater categories in terms of treatment [5]. In Tunisia, LFL treatment stations adopt an approach consisting of: Coagulation-flocculation, flotation, aerobic treatment, ultra filtration and reverse osmosis, with the aim to meet discharge standards in the natural environment. However, several problems, particularly those related to the effectiveness of leachate treatments are subject to be discussed. They include the poor optimization of the coagulation flocculation process, which may lead sometimes to the elimination of this step, the clogging of the membranes, the dysfunction of the aerobic treatment. Because of these problems, only $1 / 3$ of the leachate is treated and the storage basins are filled with untreated leachate [6]. In addition, this treatment is expensive with a low yield. Simpler process is then required to better suit the nature of the substrate. On the other hand, several studies reported wastewater treatment through physicochemical methods such as photocatalytic degradation [7], adsorption [8] and biosorption [9]. Biological processes are also applied successfully thanks to their efficiency and simplicity [10]. They offer cost effective removal of organic compounds and ammonia nitrogen, leading to a good quality effluent, and preventing pollution transfer [3]. Anaerobic treatment is an efficient biotechnological treatment of highly concentrated organic wastewater. It is one of the most energy-efficient and environmental friendly technologies due to the biogas generation and the low production of sludge [4, 11]. The purposeful utilization of LFL for bioenergy through non-thermal biological methods such as anaerobic digestion (AD) could be a suitable option to tackle the leachate disposal issue. However, there are limited studies on $\mathrm{AD}$ for the treatment of LFL for biogas generation [12]. The high organic matter content of Tunisian LFL makes it an attractive substrate for biogas production. Moreover, due to the energy deficit in Tunisia, anaerobic
This is an Open Access article distributed under the terms of the Creative Commons Attribution Non-Commercial License (http://creativecommons.org/licenses/by-nc/3.0/) which permits unrestricted non-commercial use, distribution, and reproduction in any medium, provided the original work is properly cited.
Received August 1, 2018 Accepted February 12, 2019

${ }^{\dagger}$ Corresponding author

Email: smaoui_yosr@yahoo.fr

Tel: +216-58-532-310 Fax: +216-74-665-190

Copyright (C) 2020 Korean Society of Environmental Engineers 
treatment presents the best alternative for the leachate treatment. Especially that this treatment is not yet applied in our country. Various anaerobic systems were used for LFL treatment, such as the upflow anaerobic sludge blanquet reactors [13, 14], membrane bioreactor [15], sequencing batch reactors [16] and fixed bed reactors [17]. The latter type of reactor attracts more attention following its low sensitivity to toxic compounds, great bio catalytic stability, long microbial residence time and tolerance to oligotrophic conditions [18, 19]. However, the elevated concentration of nitrogen contained in the Tunisian leachate can decrease the anaerobic treatment efficiency by inhibition of microbial activities, accumulation of volatile fatty acids (VFA) and decrease of the methane production [5]. Indeed, Hejnfelt et al. [20] reported that the incidence of ammonia inhibition can happen in the range of 1,500-7,000 $\mathrm{mg} / \mathrm{L}$ of total ammonia nitrogen. Hence, coupling physico-chemical and biological methods is required for the efficient treatment of LFL. Air stripping, adsorption and coagulation flocculation are the main physicochemical processes applied for leachate pre-treatment [21]. The impact of air stripping process on the methane production by $\mathrm{AD}$ of leachate heavily loaded with organic matter was not studied yet. Therefore, the biological approach that combines anaerobic and aerobic processes can be advisable as a handy tool for removing organics from LFL pretreated with air stripping method. Among the main aerobic treatments, we can highlight activated sludge [22], biofilters [23] and rotating biological contactors [24].

In this context, this study investigated the efficiency of the anaerobic treatment of LFL highly charged with organic matter. A pre-treatment using air stripping process was performed in order to reduce the nitrogen load present in leachate and which can constitute a brake on biological development. The high organic load of the Tunisian leachate needs an efficient treatment process to reach the standards of rejects. The chosen treatment is the aerobic treatment using activated sludge system. The objective of this study was to evaluate the performance of this integrated process in terms of organic matter reduction and biogas production. Organic compounds in the raw leachate after anaerobic/aerobic step were measured by gas chromatography coupled to mass spectrometry (GC-MS).

\section{Materials and Methods}

\subsection{LFL and Inoculum}

Leachate samples were collected from Sfax landfill site (Tunisia) and stored at $4^{\circ} \mathrm{C}$ until use. The main physico-chemical characteristics of raw leachate are shown in Table 1. Inoculum used for the $\mathrm{AD}$ of leachate pretreated by air stripping was prepared from an existing $\mathrm{AD}$ plant for wastewater treatment located in the North of Tunisia (Shotrana) and incubated at $37^{\circ} \mathrm{C}$ until required for the usage in experiments. Total solids (TS) of $55 \mathrm{~g} / \mathrm{L}$, chemical oxygen demand (COD) of $35 \mathrm{~g} / \mathrm{L}$ and $\mathrm{pH}$ of 7.9 characterized anaerobic inoculum. Aerobic sludge comes from the biological basin located in the wastewater treatment plant (WWTP) of Sfax, south Tunisia. It is characterized by a COD of $0.9 \mathrm{~g} / \mathrm{L}$, TS of $4 \mathrm{~g} / \mathrm{L}$ and a $\mathrm{pH}$ of 7.5 .
Table 1. Main Characteristics of LFL

\begin{tabular}{lccc}
\hline Characteristics & Unit & Values & LLD $^{\mathbf{a}}$ \\
$\mathrm{pH}$ & & $7.9 \pm 0.2$ & $6.5-9$ \\
$\mathrm{EC}$ & $\mathrm{mS} / \mathrm{cm}$ & $30 \pm 0.5$ & $\mathrm{nd}^{\mathrm{b}}$ \\
$\mathrm{COD}$ & $\mathrm{g} / \mathrm{L}$ & $30 \pm 0.2$ & 1 \\
$\mathrm{BOD}_{5}$ & $\mathrm{go} / \mathrm{L}$ & $9 \pm 0.2$ & 0.4 \\
$\mathrm{NTK}^{+}$ & $\mathrm{g} / \mathrm{L}$ & $3.2 \pm 0.2$ & 0.1 \\
$\mathrm{NH}_{4}{ }^{+}$ & $\mathrm{g} / \mathrm{L}$ & $2.8 \pm 0.2$ & $\mathrm{nd}^{\mathrm{b}}$ \\
$\mathrm{TS}$ & $\mathrm{g} / \mathrm{L}$ & $40 \pm 0.2$ & $\mathrm{nd}^{\mathrm{b}}$ \\
$\mathrm{VFA}$ & $\mathrm{g} / \mathrm{L}$ & $7 \pm 0.2$ & $\mathrm{nd}^{\mathrm{b}}$ \\
\hline
\end{tabular}

$L L D^{\text {a }}$ : legal limits for discharge into urbanized streams (NT. 106.002); $\mathrm{nd}^{\mathrm{b}}$ : not determined

\subsection{Analytical Methods}

The $\mathrm{pH}$, electrical conductivity (EC), TS and volatile solids (VS) were based on the standard methods [25]. COD was determined according to Knechtel [26], biochemical oxygen demand (BOD $)$ was estimated according to manometric method, total and ammoniacal nitrogen were analyzed by Kjeldahl method and VFA were analyzed using a GC-17A gas chromatograph equipped with a capillary column (Nukol: $30 \mathrm{~m} \_0.32 \mathrm{~m}$ ) and a flame ionization detector.

\subsection{Biochemical Methane Potential (BMP) Tests}

The effect of air stripping pretreatment on the biogas production was studied by applying the BMP test. The experiments were conducted at $37^{\circ} \mathrm{C}$ using $500 \mathrm{~mL}$ glass bottles as reactors. LFL and acclimated anaerobic sludge were added to bottles, keeping a VS ratio (VS substrate to VS inocula) of 1:1 [27] and the working volume was adjusted to $250 \mathrm{~mL}$. The initial concentration of raw and pretreated leachate are 30 and $28 \mathrm{~g} / \mathrm{L}$ of COD, respectively. Based on the initial VS contents of LFL samples (12 g/L) and inocula (20 g/L), the volumes ratio used are 93 and $157 \mathrm{~mL}$ for inocula and substrate, respectively. A control batch only with inoculum was used. After adjusting the $\mathrm{pH}$ to 7.0, bottles were flushed with $\mathrm{N}_{2}$ for 3 min to supply anaerobic conditions and then incubated in a temperature-controlled room. The measurement of the methane produced was determined using an alkaline solution $(\mathrm{NaOH} 5 \%$ $(\mathrm{w} / \mathrm{v})$ ) instead water prior the gas displacement device [28].

\subsection{Chromatographic Analysis}

Samples of raw and treated leachate were collected and analyzed by GC-MS in order to identify the organic compounds. Samples of $500 \mathrm{~mL}$ of leachate were prepared according to Ramírez-Sosa et al. [29]. They were extracted three times by $50 \mathrm{~mL}$ of dichloromethane, after adjusting the $\mathrm{pH}$ to 12 using $\mathrm{NaOH} 10 \mathrm{~N}$. The organic fraction was then recovered in a flask, and the aqueous fraction was subjected again to liquid extraction using dichloromethane after adjusting its $\mathrm{pH}$ to 2 . The separated acidic and alkaline organic phases were mixed. They were condensed to $5 \mathrm{~mL}$ in a rotoevaporator and a water bath at $42^{\circ} \mathrm{C}$. The condensed fraction was diluted with dichloromethane to $1 \mathrm{~mL}$ in an Agilent chromatographic vial and then analyzed by GC-MS using an Agilent 7890A gas chromatograph coupled to an Agilent 7,000 triple quad mass 
spectrophotometer. The column used for chromatographic separation was an HP-5MS $(30 \mathrm{~m} \times 0.25 \mathrm{~mm} \times 0.25 \mu \mathrm{m}$, Agilent Technologies). The oven was programmed to start at $80^{\circ} \mathrm{C}$ for 5 min, ramp at $5^{\circ} \mathrm{C} / \mathrm{min}$ until $240^{\circ} \mathrm{C}$, set at $240^{\circ} \mathrm{C}$ for $10 \mathrm{~min}$, then ramp at $10^{\circ} \mathrm{C} / \mathrm{min}$ to $290^{\circ} \mathrm{C}$ and finally set at $290^{\circ} \mathrm{C}$ for $5 \mathrm{~min}$.

\subsection{Experimental Procedure}

The treatment plant was shown in Fig. S1. Experiments were conducted at the laboratory scale.

\subsubsection{Air stripping}

The experiments were conducted in triplicate at $10 \mathrm{~L}$ column with aeration rate of $7 \mathrm{~L} / \mathrm{min}$ and at room temperature $\left(25 \pm 2{ }^{\circ} \mathrm{C}\right)$. The $\mathrm{pH}$ and reaction time were fixed at 11 and $18 \mathrm{~h}$ according to Smaoui et al. [30].

\subsection{2. $A D$ of $L F L$}

Upflow anaerobic fixed bed reactor (UAFB) was used for leachate digestion. It consists of a circular column with $64 \mathrm{~cm}$ in height and $17 \mathrm{~cm}$ in diameter, offers an effective volume of $7 \mathrm{~L}$ and was packed with plastic carriers (type HIFLOWE, cylindrical shape with a specific area of $70 \mathrm{~m}^{2} \mathrm{~m}^{-3}$ ). The $\mathrm{AD}$ was performed at $37^{\circ} \mathrm{C}$. Daily biogas produced was measured using a gas meter. The methane content was measured at the end of each organic loading rate (OLR) by using an alkaline solution, prior to the gas meter, which effectively absorbs all the carbon dioxide in the off-gas [28].

To study the OLR impact on the performance of the treatment process, the anaerobic treatment was performed using a raw and diluted (1:2) LFL.

\subsubsection{Aerobic treatment of LFL}

Aerobic treatment using activated sludge system was applied as a post treatment. The reactor used had an effective volume of $10 \mathrm{~L}$. An aeration flow of $7 \mathrm{~L} / \mathrm{min}$ was applied using a diffuser. The temperature was maintained constant at $30^{\circ} \mathrm{C}$ with a continuous rotation by a stirring system included in the reactor. Aerobic sludge was mixed with treated LFL at a proportion of 1:2 (v/v). The activated sludge system was fed discontinuously with treated LFL for one time. The ability of the biomass to degrade the OM was monitored by measuring the COD removal during a period of $17 \mathrm{~d}$.

\section{Results and Discussion}

\subsection{LFL Characteristics}

LFL presents an alkaline $\mathrm{pH}$ associated with high EC. This can be justified by the solubility of chloride concentration in solution [31]. The COD content has shown an average value of $30 \mathrm{~g} / \mathrm{L}$. The high amount of organic matter makes LFL an attractive substrate for biogas production. The dark color of LFL is explained by the presence of a high content of humic substances [17]. The LFL is characterized by high ammonia concentration ( $3 \mathrm{~g} / \mathrm{L})$ which may cause an inhibition of methanation. In fact, the suitable carbon to nitrogen $(\mathrm{C} / \mathrm{N})$ ratio for the methanogenic step is in the range of 20-30 [27]. So the first process applied was the air stripping in order to obtain a $\mathrm{C} / \mathrm{N}$ ratio suitable for the $\mathrm{AD}$.

\subsection{Air Stripping as a Pretreatment of $A D$}

Air stripping was chosen as a pretreatment process to reduce ammonia from LFL and improve the $\mathrm{AD}$. This process is simple and cheaper than other physico-chemical methods with no extra sludge [23]. The application of this process allowed $85 \%$ of ammonia reduction and the concentration varied from $2.8 \mathrm{~g} / \mathrm{L}$ to $0.5 \mathrm{~g} / \mathrm{L}$ for the untreated and treated leachate, respectively. Following this reduction, the $\mathrm{C} / \mathrm{N}$ ratio was improved to $25 \pm 0.7$ which is favorable for the anaerobic treatment [32]. Therefore BMP test was performed to ascertain the importance of air stripping in improving methane production during further $\mathrm{AD}$ of leachate (Fig. 1). It is clear that ammonia stripping significantly enhanced the methanization of LFL in comparison to raw one. At the end of the experiment, the production of methane increased by $60 \%$ for stripped leachate in comparison to the raw leachate. In fact, starting from a raw leachate containing $2.8 \mathrm{~g} / \mathrm{L}$ ammonia, the addition of a volume of anaerobic sludge inocula led to a dilution of ammonia concentration. However, since the ammonia concentration of sludge is about $0.25 \mathrm{~g} / \mathrm{L}$, the final mixture content was about $1.9 \mathrm{~g} / \mathrm{L}$. As a consequence, $\mathrm{C} / \mathrm{N}$ ratio remains low with a value of 3.5 and not suitable for $\mathrm{AD}$ which can cause inhibition of methanogenesis. For the bottles containing leachate pretreated by air stripping, the ammonia concentration was about $0.4 \mathrm{~g} / \mathrm{L}$, and the $\mathrm{C} / \mathrm{N}$ ratio reach a value of 21 which can be considered as suitable for $\mathrm{AD}$. We can conclude from the batch study that methane production could be due to the degradation of the high strength organic compounds of LFL and decomposition of the non-biodegradable organic macromolecules to biodegradable VFA with improved biodegradability [33]. Air stripping contributes to reduce the $\mathrm{NH}_{4}$ content responsible for leachate toxicity. These results are correlated with those of Liu et al. [34] who indicated that high ammonia concentration can inhibit microbial activities, and so it should be kept below $1,000 \mathrm{mg} / \mathrm{L}$. Chen et al. [35] reported that values of ammonia concentration causing $50 \%$ of methane production reduction range from 1.7 to $14 \mathrm{~g} / \mathrm{L}$. Yang et al. [36] showed that more than $20 \%$ of methane production loss was observed in mesophilic reactors when the ammonia level exceeded 2 g/L. Hobson and Shaw [37] reported that ammonia concentration of $2.5 \mathrm{~g} / \mathrm{L}$ resulted in some inhibition of methane production, while a concentration of $3 \mathrm{~g} / \mathrm{L}$ inhibited methanogenesis completely. The study

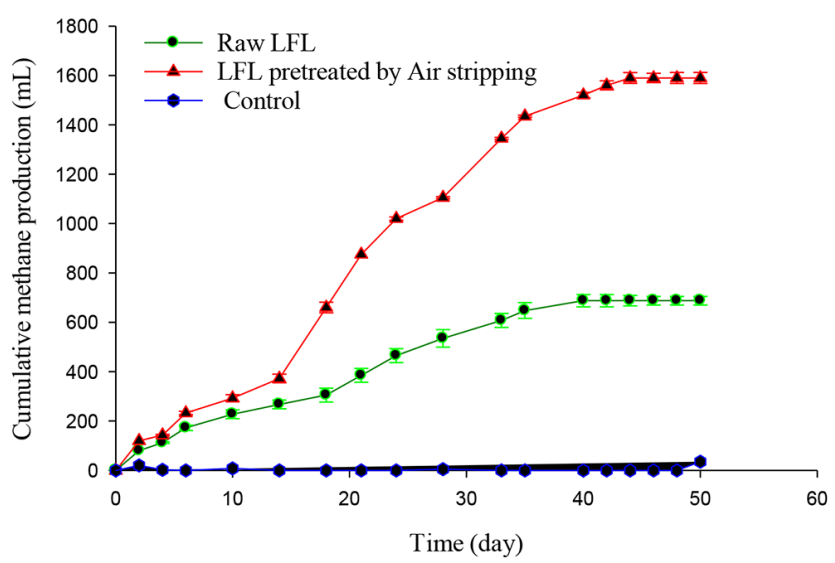

Fig. 1. Cumulative methane production during batch anaerobic treatment. 
reported by el Gohary et al. [38] showed that the use of ammonia stripping improved COD and BOD removal which may improve the leachate biodegradability and improve the volume of biogas released. In addition, Zhang et al. [23] showed an enhanced bio-methanization of piggery wastewater after removal of $80 \%$ ammonia by air stripping treatment.

The leachate treated by ammonia stripping is subsequently used in the $\mathrm{AD}$.

\section{3. $A D$ of $L F L$}

A UAFB reactor was used for $\mathrm{AD}$ experiment. This reactor is the most favored in this case because it makes possible to treat the highly charged effluents while remaining stable even with the variability of the leachate composition and the operating conditions [39]. The decay of organic matter was followed by tracking the soluble COD in the effluent. The reactor was fed with pre-treated LFL. At the first stage, the LFL was used without any dilution. In fact, the high organic matter concentration stimulated the growth of bacteria, that consumed biodegradable organic compounds and then increased the COD removal [40]. During the start-up phase, the anaerobic reactor was discontinuously fed with pre-treated $\mathrm{LFL}$ at a low OLR $(0.2 \mathrm{~g}$ COD/L/d) until acclimatation of the biomass. After exhaustion of the biogas released by the sludge, increasing loads of leachate ranging from 0.5 to $2 \mathrm{~g} \mathrm{COD} / \mathrm{L} / \mathrm{d}$ were applied. For these loads, the hydraulic retention time (HRT) decreased from 30 to $14 \mathrm{~d}$ (Table 2). The obtained results showed that the COD removal efficiency increases gradually with increasing OLR to reach its maximum of $70 \%$ with a load of $1.5 \mathrm{~g} \mathrm{COD/L/d} \mathrm{(Fig.} \mathrm{2(a)).}$ These results are in agreement with other studies which indicated that COD removal increased with increasing organic matter concentration in $\mathrm{AD}[17,38]$. In general, the efficiency of the $\mathrm{AD}$ process is determined by measuring the production of the biogas, which depends on the nature of the substrate to be treated. For this, the daily monitoring of the biogas production shows that it improves gradually with the increase of the organic load applied. A maximum volume of $4 \mathrm{~L}$ of biogas is obtained for a load of $1.5 \mathrm{~g} \mathrm{COD} / \mathrm{L} / \mathrm{d}$. The percentage of methane released is between $70 \%$ and $80 \%$ of the total volume of biogas produced. The continuous production of methane indicates that the methanogenic bacteria degraded the organic matter during the process [41]. The increase in OLR to $2 \mathrm{~g} \mathrm{COD} / \mathrm{L} / \mathrm{d}$ reduced the performance of the bioreactor in terms of COD removal and biogas production (Fig. 2) and reach at the end of treatment $72 \%$ and $3 \mathrm{~L} / \mathrm{d}$, respectively. This can be explained by the destabilization of the process due to the high OLR and to the quality of the influent [42]. In fact, the high salinity of leachate can affect the bacterial population responsible for the degradation of organic matter. In addition, Rahayu et al. [43] explain the decrease of COD removal efficiency by the decrease of the amount of the biodegradable COD. This can also be attributed to the accumulation of volatile fatty acids in the reactor, which have a disruptive effect and cause an imbalance in the process of $\mathrm{AD}[5,44]$.

To study the effect of organic matter concentration on the efficiency of the $\mathrm{AD}$ and to improve the performance of the reactor, a diluted LFL (1:2) was used in the next step. Since the reactor was previously acclimated to leachate, it was restarted with an
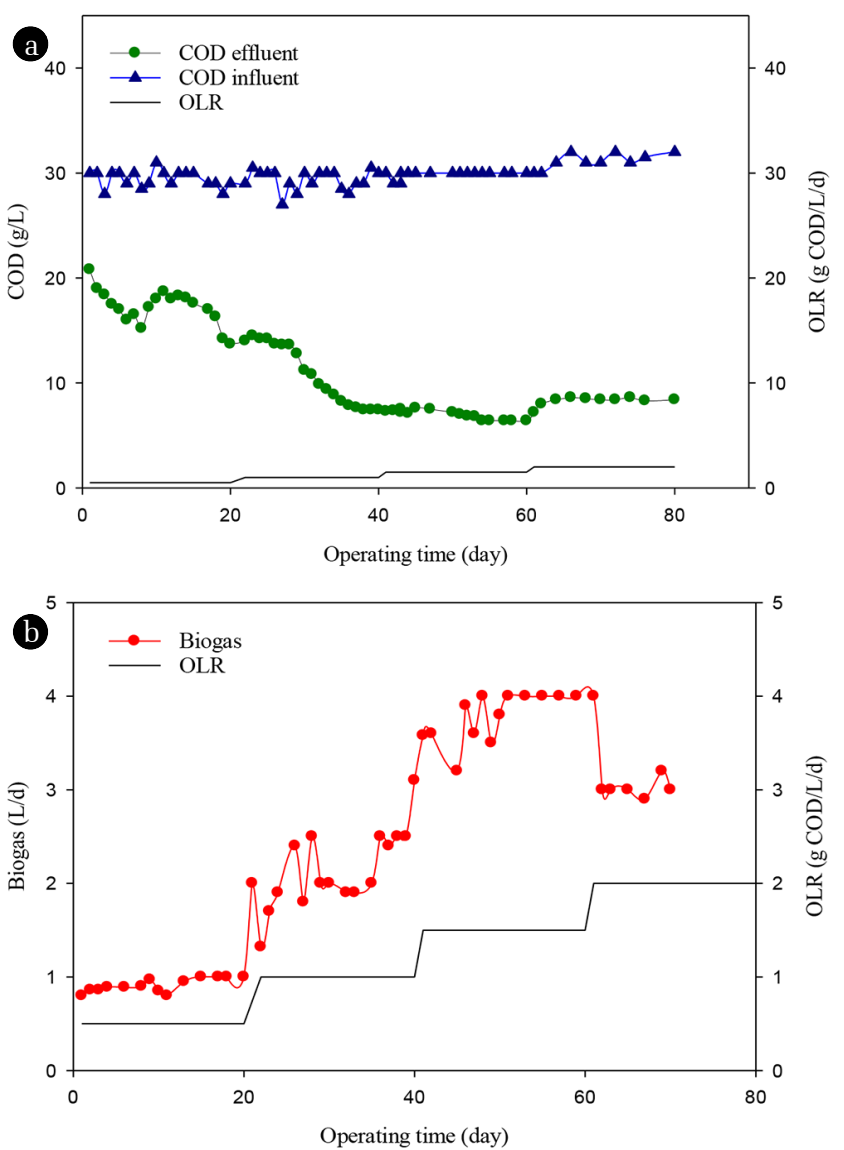

Fig. 2. Anaerobic digestion of undiluted LFL in the UAFB reactor: (a) COD evolution and (b) biogas production during the increase of the OLR.

Table 2. Operating Conditions and Average Performance during LFL (1:1) Treatment in the UAFB Reactor

\begin{tabular}{l|cccc}
\hline Theoretical OLR (g COD/L/d) & 0.5 & 1 & 1.5 & 2 \\
HRT (d) & 60 & 30 & 20 & 14 \\
COD feed (g/L) & 30 & 30 & 30 & 30 \\
COD removal (\%) & 53 & 75 & 78 & 71 \\
Biogas produced (L/d) & 1 & 2.5 & 4 & 3.1 \\
\hline
\end{tabular}

Table 3. Operating Conditions and Average Performance during LFL (1:2) Treatment in the UAFB Reactor

\begin{tabular}{l|ccccc}
\hline Theoretical OLR (g COD/L/d) & 1 & 1.5 & 2 & 3 & 3.2 \\
HRT (d) & 14 & 10 & 7 & 5 & 4 \\
COD feed (g/L) & 15 & 15 & 15 & 15 & 15 \\
COD removal (\%) & 57.6 & 65 & 78 & 81 & 64 \\
Biogas produced (L/d) & 3 & 4.2 & 5.5 & 7.4 & 5 \\
\hline
\end{tabular}

organic load of $1 \mathrm{~g}$ COD/L/d and then increased gradually $3.2 \mathrm{~g}$ COD/L/d (Table 3). The reactor was fed with $\mathrm{LFL}$ having a soluble COD of $15 \mathrm{~g} / \mathrm{L}$ and the HRT was fixed at $5 \mathrm{~d}$. Under these conditions, the COD removal reached a maximum of $80 \%$ (Fig. 3(a)) with 

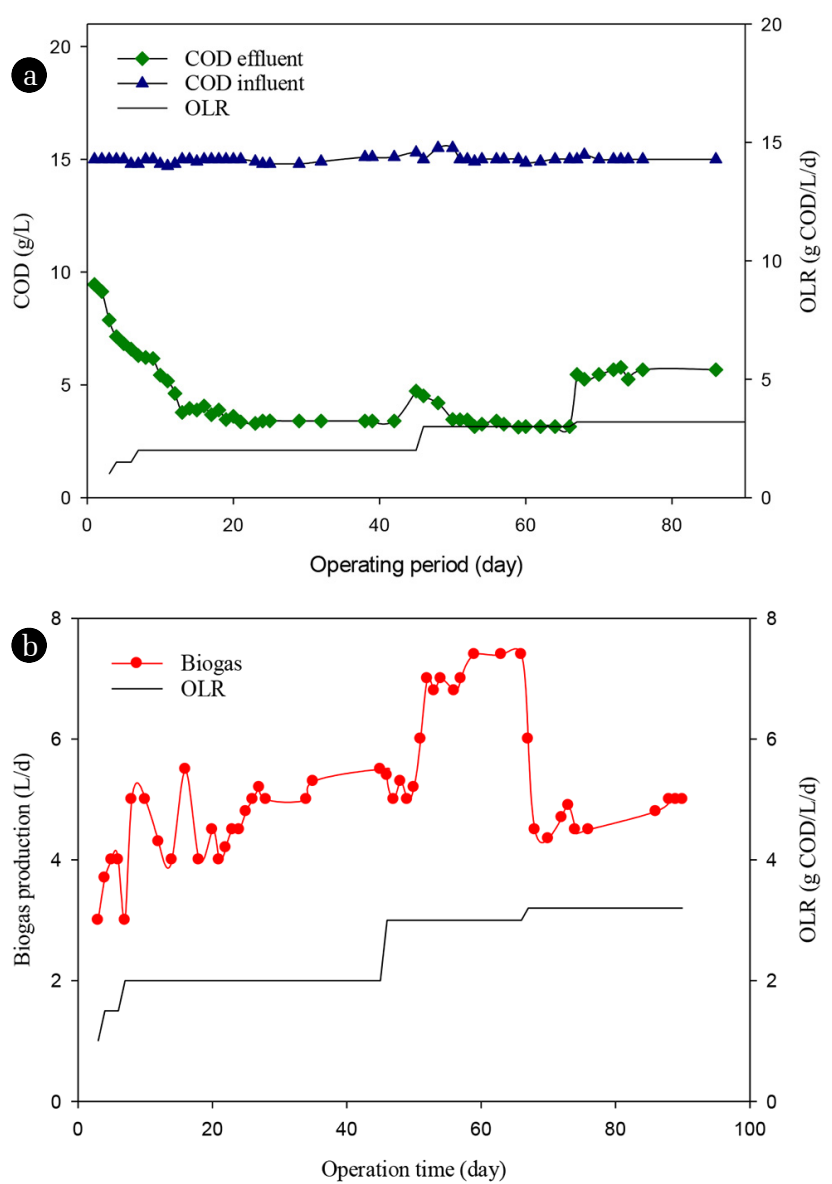

Fig. 3. Anaerobic digestion of diluted LFL in the UAFB reactor: (a) $\mathrm{COD}$ evolution in the influent and the effluent during the increase of the OLR and (b) biogas production during the increase of the OLR.

a production of biogas superior to $7 \mathrm{~L} / \mathrm{d}$ when the OLR applied was fixed to $3 \mathrm{~g}$ COD/L/d (Table 3). The methane content represents $70 \%$ of the biogas produced (Fig. 3(b)). These results are very interesting in comparison with other studies. Zayen et al. [17] obtained a 74\% of COD removal with only $1 \mathrm{~L}$ biogas/d produced, when treating raw leachate with an initial COD of 15 g/L. In addition, Gohary et al. [38] achieved a COD reduction of $41 \%$ by applying the anaerobic treatment to treat leachate pretreated by air stripping. The increase of OLR from 3 to 3.2 g COD/L/d, contributed to a decrease of COD removal and a fluctuation in the biogas production, which may be due to disequilibrium of the anaerobic process. These data suggest that the use of UAFB reactor can provide a good LFL treatment by reduction of organic matter of $80 \%$ and a biogas production of $74 \%$. Indeed, lower LFL treatment performances were described in other studies. For example, Zolfaghari et al. [45] showed a reduction of $63 \%$ of COD when using an OLR of $1.2 \mathrm{~g} \mathrm{COD} / \mathrm{L} / \mathrm{d}$ in MBR. A reduction of $62 \%$ of $\mathrm{COD}$ and a methane production of $0.34 \mathrm{~L} / \mathrm{g}$ COD eliminated were obtained by Xie et al. [46] by treating LFL in MBR.

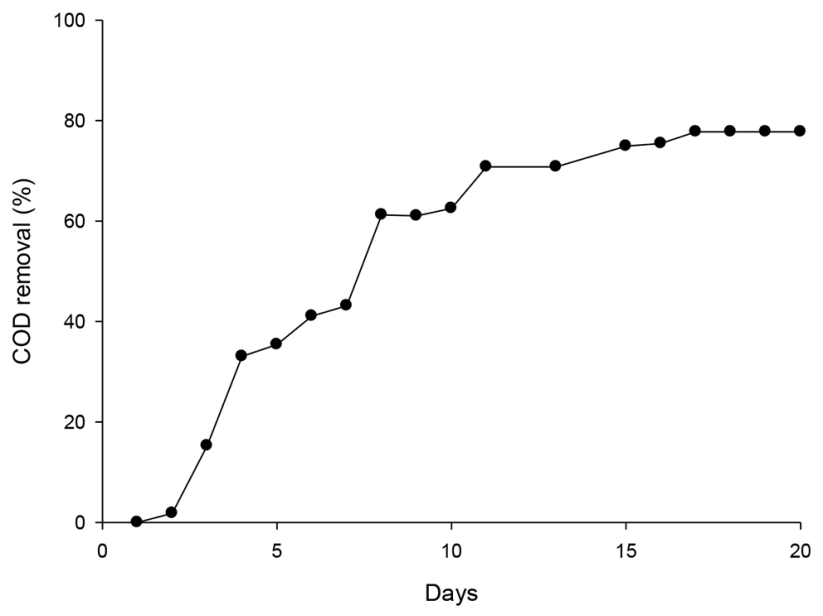

Fig. 4. Variations of COD removal of LFL during activated sludge system treatment.

Despite the interesting results found with $\mathrm{AD}$, the resulting effluent is still not in compliance with the discharge standard allowed by Tunisian environmental legislation especially for the COD (2.8 $\mathrm{g} / \mathrm{L}>1 \mathrm{~g} / \mathrm{L}$ ). Therefore, it is essential to carry out a post treatment to reduce the concentration of resistant pollutants.

\subsection{Aerobic Activated Sludge as a Post Treatment}

The post-treatment is inevitably applied to guarantee that effluent satisfy the Tunisian strict discharge criteria (NT 106.02). The activated sludge bioreactors were successfully used in conventional wastewater treatment to achieve higher effluent quality [47]. The effluent resulting from the $\mathrm{AD}$ with $\mathrm{COD}$ of $3 \mathrm{~g} / \mathrm{L}$ was used as an influent for activated sludge system. The bioreactor containing 3.5 L of activated sludge was fed discontinuously with $6.5 \mathrm{~L}$ of treated LFL. The performance of the activated sludge reactor is illustrated in Fig. 4. The results showed that COD removal efficiency increased gradually with time. Therefore, the maximum COD removal was obtained after $17 \mathrm{~d}$ of treatment and achieved $77 \%$. Thus, applying activated sludge system as post treatment is very important because it leads to a final effluent that can satisfy the Tunisian limit of discharge.

\subsection{Determination of Organic Components in Leachate by GC-MS Analysis}

An analysis of the organic matter components of raw and treated LFL by anaerobic-aerobic process was performed (Table 4). The compounds present in the leachate samples with spectra signal quality (> 95\%) were separated and identified by GC-MS. Fig. S2 shows that the total corrected area of the raw LFL is high compared to the total corrected area of treated LFL. In fact, 26 distinct chromatographic peaks were identified in the raw LFL. The major components identified are phthalates (Phthalic acid, Phthalic acid bis(2 pentyl) ester) and acids (Hexanedioic acid, Heptanedioic acid, Benzeneacetic acid). These components are usually detected in LFL of many countries [29, 48] and known by their toxicities and negative impact on the environment. From the Table 4, we can conclude that the corrected area of LFL treated by anaerobic-aerobic 
Table 4. List of Compounds Detected in Landfill Leachate

\begin{tabular}{|c|c|c|c|c|c|c|}
\hline \multirow[t]{2}{*}{ Compounds } & \multicolumn{2}{|c|}{ Raw Leachate } & \multicolumn{2}{|c|}{ Leachate1 $^{*}$} & \multicolumn{2}{|c|}{ Leachate2 $^{* *}$} \\
\hline & $\begin{array}{l}\text { Retention time } \\
\text { (min) }\end{array}$ & $\begin{array}{l}\text { Corrected } \\
\text { area }\end{array}$ & $\begin{array}{l}\text { Corrected } \\
\text { area }\end{array}$ & $\begin{array}{c}\% \\
\text { Removal }\end{array}$ & $\begin{array}{l}\text { Corrected } \\
\text { area }\end{array}$ & $\begin{array}{c}\% \\
\text { Removal }\end{array}$ \\
\hline Hexanedioic acid, bis (trimethylsilyl) ester & 4.79 & 128862370 & 33454550 & 74.04 & nd & 100 \\
\hline Heptanedioic acid, bis (trimethylsilyl) ester & 5.45 & 11963341 & 5645722 & 52.80 & nd & 100 \\
\hline $\begin{array}{l}\text { Benzeneacetic acid, 3-[(trimethylsilyl) } \\
\text { oxy]-, trimethylsilyl ester }\end{array}$ & 5.53 & 7385486 & nd & 100 & nd & 100 \\
\hline $\begin{array}{l}\text { Benzoic acid, 4-[(trimethylsilyl)oxy], } \\
\text { trimethylsilyl ester }\end{array}$ & 5.69 & 9082462 & nd & 100 & nd & 100 \\
\hline $\begin{array}{l}\text { Benzeneacetic acid, 4-[(trimethylsilyl) } \\
\text { oxy]-, trimethylsilyl ester }\end{array}$ & 5.77 & 10269156 & nd & 100 & nd & 100 \\
\hline $\begin{array}{l}\text { 3-Amino-5-cyano-7-ethoxy-2-formyl-4-ph } \\
\text { enylthieno[2,3-b]pyridine }\end{array}$ & 5.86 & 9562536 & nd & 100 & nd & 100 \\
\hline Octanedioic acid, bis (trimethylsilyl) ester & 6.26 & 52437967 & 14675254 & 72 & nd & 100 \\
\hline $\begin{array}{l}\text { Pentanedioic acid, 2,2,3-trimethyl-, bis } \\
\text { (trimethylsilyl) ester }\end{array}$ & 6.47 & 8676171 & nd & 100 & nd & 100 \\
\hline $\begin{array}{l}\text { Benzenepropanoic acid, 3-[(trimethylsilyl) } \\
\text { oxy]-, trimethylsilyl ester }\end{array}$ & 6.61 & 47779300 & 10475555 & 78.05 & nd & 100 \\
\hline AZELAIC ACID-DITMS & 7.34 & 167700005 & 41987244 & 74.96 & nd & 100 \\
\hline $\begin{array}{l}\text { 1,2-Benzenedicarboxylic acid, } \\
\text { bis(2-methylpropyl) ester }\end{array}$ & 8.48 & 54304721 & 16084391 & 70.38 & 1097347 & 97.97 \\
\hline Sebacic acid, bis(trimethylsilyl) ester & 8.85 & 27990015 & 2885934 & 89.68 & nd & 100 \\
\hline $\begin{array}{l}\text { Benzenedicarboxylic acid, butyl } \\
\text { cyclohexyl ester }\end{array}$ & 9.31 & 151807897 & nd & 100 & nd & 100 \\
\hline $\begin{array}{l}\text { Benzenedicarboxylic acid, } \\
\text { bis(2-methylpropyl) ester }\end{array}$ & 9.68 & 51691362 & 32619763 & 36.89 & 30619763 & 40.76 \\
\hline Benzenedicarboxylic acid, dibutyl ester & 10.28 & 103349944 & nd & 100 & nd & 100 \\
\hline $\begin{array}{l}\text { 1,2-Benzenedicarboxylic acid, dibutyl } \\
\text { ester }\end{array}$ & 10.47 & 27747465 & 646875 & 97.66 & nd & 100 \\
\hline Phthalic acid, butyl isohexyl ester" & 10.75 & 56395469 & 279470 & 99.5 & nd & 100 \\
\hline $\begin{array}{l}\text { 1,3-Benzodioxole-6-carboxamide, } \\
\mathrm{N}-(2 \text { '-benzoylphenyl) }\end{array}$ & 10.95 & 12031538 & nd & 100 & nd & 100 \\
\hline Phthalic acid, bis(2-pentyl) ester & 11.27 & 4472031 & nd & 100 & nd & 100 \\
\hline Hexadecanoic acid, trimethylsilyl ester & 12.35 & 41484606 & 17095406 & 57.8 & 7447326 & 80.04 \\
\hline Octadecenoic acid (Z)-, methyl ester & 14.11 & 15148482 & 5011653 & 66.91 & nd & 100 \\
\hline is, 6-Octadecenoic acid, trimethylsilyl ester & 19.51 & 15303740 & nd & 100 & nd & 100 \\
\hline 2,2-Bis[(4-trimethylsiloxy)phenyl]propane & 19.9 & 24259720 & nd & 100 & nd & 100 \\
\hline Octadecanoic acid, trimethylsilyl ester & 21 & 25342317 & nd & 100 & nd & 100 \\
\hline Decanoic acid, trimethylsilyl ester & 27.5 & 10131951 & nd & 100 & nd & 100 \\
\hline $\begin{array}{l}\text { 1,2-Benzenedicarboxylic acid, } \\
\text { mono(2-ethylhexyl) ester }\end{array}$ & 30.9 & 131577018 & 79147538 & 39.84 & 77147538 & 41.36 \\
\hline Total corrected area & & 1226757070 & 264145018 & 78.47 & 29166523 & 98 \\
\hline
\end{tabular}

$1^{*}$ Leachate treated by air stripping-anaerobic digestion

$2^{* *}$ Leachate treated by air stripping-anaerobic digestion-activated sludge nd. Not determined 
process decreased 98\% in comparison with the corrected area of the raw LFL. The results illustrated an almost complete elimination of the organic compounds present in the raw effluent and thus confirm the effectiveness of applied biological treatments (AD-activated sludge) adopted for the treatment of Tunisian LFL.

\section{Conclusions}

This study showed that LFL is characterized by a high organic matter, with low biodegradability. It has also a high salts and ammonia content. The air stripping pre-treatment achieved over $80 \%$ ammonia removal, which contributed to an increase of the biodegradability and the $\mathrm{C} / \mathrm{N}$ ratio. The anaerobic treatment was successfully applied for the removal of organic matter, 78\% of COD removal for an OLR of $1.5 \mathrm{~g}$ COD/L/d and with undiluted LFL. The biogas produced was of $4 \mathrm{~L} / \mathrm{d}$. The use of diluted leachate improved the degradation process leading to a COD removal efficiency of $81 \%$ for an OLR of $3 \mathrm{~g}$ COD/L/d and a HRT of $4 \mathrm{~d}$. The biogas production was $7.2 \mathrm{~L} / \mathrm{d}$ with $75 \%$ of methane content. The application of activated sludge reactor as a post treatment let to remove the resistant organic matter and production of an effluent that satisfies the discharge standard allowed by Tunisian environmental legislation. The GCMS analysis confirmed the effectiveness of the process adopted.

\section{Acknowledgments}

The authors express their gratitude to the Environmental Bioprocesses Laboratory, Centre of Biotechnology of Sfax, for providing us with facilities and support during the present study.

We wish to extend our thanks to the ANGED (Tunisia) for the help during leachate sample collection.

\section{References}

1. Kawai M, Purwanti IF, Nagao N, Slamet A, Hermana J, Toda T. Seasonal variation in chemical properties and degradability by anaerobic digestion of landfill leachate at Benowo in Surabaya, Indonesia. J. Environ. Manage. 2012;110:267-275.

2. Müller GT, Giacobbo A, dos Santos Chiaramonte EA, Siqueira Rodrigues MA, Meneguzzi A, Bernardes AM. The effect of sanitary landfill leachate aging on the biological treatment and assessment of photoelectrooxidation as a pre-treatment process. Waste Manage. 2015;36:177-183.

3. Sun H, Peng Y, Shi X. Advanced treatment of landfill leachate using anaerobic-aerobic process: Organic removal by simultaneous denitritation and methanogenesis and nitrogen removal via nitrite. Bioresour. Technol. 2015;177:337-345.

4. Contrera RC, da Cruz Silva KC, Morita DM, Domingues Rodrigues JA, Zaiat M, Schalch V. First-order kinetics of landfill leachate treatment in a pilot-scale anaerobic sequence batch biofilm reactor. J. Environ. Manage. 2014;145:385-393.

5. Dai X, Li X, Zhang D, Chen Y, Dai L. Simultaneous enhancement of methane production and methane content in biogas from waste activated sludge and perennial ryegrass anaerobic co-di- gestion: The effects of $\mathrm{pH}$ and $\mathrm{C} / \mathrm{N}$ ratio. Bioresour. Technol. 2016;216:323-330.

6. Smaoui Y. Détoxification et traitement-valorisation par voie anaérobie des lixiviats jeunes: Cas du Centre d'Enfouissement Technique d'Aguereb. [dissertation]. Tunisie: National School of Engineers of Sfax. 2017.

7. Alansi AM, Al-Qunaibit M, Alade IO, Qahtan FT, Saleh TA. Visible-light responsive $\mathrm{BiOBr}$ nanoparticles loaded on reduced graphene oxide for photocatalytic degradation of dye. J. Mol. Liq. 2018;253:297-304.

8. Saleh TA, Gupta VK. Processing methods, characteristics and adsorption behavior of tire derived carbons: A review. $A d v$. Colloid Interface Sci. 2014;211:93-101.

9. Tka N, Jabli M, Saleh TA, Salmen AG. Amines modified fibers obtained from natural Populus tremula and their rapid biosorption of Acid Blue 25. J. Mol. Liq. 2018;250:423-432.

10. Peng Y, Zhang S, Zeng W, Zhenga S, Minoc T, Satohc H. Organic removal by denitritation and methanogenesis and nitrogen removal by nitritation from landfill leachate. Water Res. 2008;42:883-892.

11. Jin Y, Li Y, Li J. Influence of thermal pretreatment on physical and chemical properties of kitchen waste and the efficiency of anaerobic digestion. J. Environ. Manage. 2016;180:291-300.

12. Begum S, Anupoju GR, Sridhar S, Bhargava SK, Jegatheesan V, Eshtiaghi N. Evaluation of single and two stage anaerobic digestion of landfill leachate: Effect of $\mathrm{pH}$ and initial organic loading rate on volatile fatty acid (VFA) and biogas production. Bioresour. Technol. 2018;251:364-373.

13. Castillo E, Vergara M, Moreno Y. Landfill leachate treatment using a rotating biological contactor and an upward-flow anaerobic sludge bed reactor. Waste Manage. 2007;27:720-726.

14. Sun H, Yang Q, Peng Y, Shi X, Wang S, Zhang S. Advanced landfill leachate treatment using a two-stage UASB-SBR system at low temperature. J. Environ. Sci. 2010;22:481-485.

15. Mnif S, Zayen A, Karray F, et al. Microbial population changes in anaerobic membrane bioreactor treating landfill leachate monitored by single-strand conformation polymorphism analysis of $16 \mathrm{~S}$ rDNA gene fragments. Int. Biodeterior. Biodegrad. 2012;73:50-59.

16. Imen S, Ismail T, Sami S, et al. Characterization and anaerobic batch reactor treatment of Jebel Chakir Landfill leachate. Desalination 2009;246:417-424.

17. Zayen A, Schories G, Sayadi S. Incorporation of an anaerobic digestion step in a multistage treatment system for sanitary landfill leachate. Waste Manage. 2016;53:32-39.

18. González AJ, Gallego A, Gemini VL, et al. Degradation and detoxification of the herbicide 2,4-dichlorophenoxyacetic acid (2,4-D) by an indigenous Delftia sp. strain in batch and continuous systems. Int. Biodeterior. Biodegrad. 2012;66:8-13.

19. Dastyar W, Amani T, Elyasi S. Investigation of affecting parameters on treating high-strength compost leachate in a hybrid EGSB and fixed-bed reactor followed by electrocoagulationflotation process. Process Saf. Environ. Prot. 2015;95:1-11.

20. Hejnfelt A, Angelidaki I. Anaerobic digestion of slaughterhouse by-products. Biomass Bioenerg. 2009;33:1046-1054.

21. Gotvajn AŽ, Tišler T, Zagorc-Končan J. Comparison of different treatment strategies for industrial landfill leachate. J. Hazard. 
Mater. 2009;162:1446-1456.

22. Mlaik N, Gouider M, Bouzid J, Belbahri L, Woodward S, Mechichi T. Treatment of unhairing effluents by activated sludge system. Environ. Prog. Sustain. Energ. 2011;30:337-346.

23. Zhang L, Lee Y-W, Jahng D. Ammonia stripping for enhanced biomethanization of piggery wastewater. J. Hazard. Mater. 2012;199-200:36-42.

24. Castrillón L, Fernández-Nava Y, Ulmanu M, Anger I, Marañón E. Physico-chemical and biological treatment of MSW landfill leachate. Waste Manage. 2010;30:228-235.

25. APHA. Standard methods for examination of water and wastewater. 18th ed. Washington D.C.: American Public Health Association; 1992.

26. Knetchel RJ. A more economical method for the determination of chemical oxygen demand. Water Pollut. Control. 1978;71:25-29.

27. Khoufi S, Louhichi A, Sayadi S. Optimization of anaerobic co-digestion of olive mill wastewater and liquid poultry manure in batch condition and semi-continuous jet-loop reactor. Bioresour. Technol. 2015;182:67-74.

28. Guwy AJ. Equipment used for testing anaerobic biodegradability and activity. Rev. Environ. Sci. Biotechnol. 2004;3:131-139.

29. Ramírez-Sosa DR, Castillo-Borges ER, Méndez-Novelo RI, Sauri-Riancho MR, Barceló-Quintal M, Marrufo-Gómez JM. Determination of organic compounds in landfill leachates treated by Fenton-Adsorption. Waste Manage. 2013;33:390-395.

30. Smaoui Y, Mlaik N, Bouzid J, Sayadi S. Improvement of anaerobic digestion of landfill leachate by using coagulation-flocculation, Fenton's oxidation and air stripping pre-treatments. Environ. Prog. Sustain. Energ. 2017;37:1041-1049.

31. Öncü G, Reiser M, Kranert M. Aerobic in situ stabilization of Landfill Konstanz Dorfweiher: Leachate quality after 1 year of operation. Waste Manage. 2012;32:2374-2384.

32. Li Y, Park SY, Zhu J. Solid-state anaerobic digestion for methane production from organic waste. Renew. Sust. Energ. Rev. 2011;15:821-826.

33. Wu L, Zhang L, Xu Y, et al. Advanced nitrogen removal using bio-refractory organics as carbon source for biological treatment of landfill leachate. Sep. Purif. Technol. 2016;170:306-313.

34. Liu Z, Dang Y, Li C, Sun D. Inhibitory effect of high $\mathrm{NH}_{4}{ }^{+-} \mathrm{N}$ concentration on anaerobic biotreatment of fresh leachate from a municipal solid waste incineration plant. Waste Manage. 2015;43:188-195.

35. Chen Y, Cheng JJ, Creamer KS. Inhibition of anaerobic digestion process: A review. Bioresour. Technol. 2008;99:4044-4064.

36. Yang Z, Wang W, He Y, Zhang R, Liu G. Effect of ammonia on methane production, methanogenesis pathway, microbial community and reactor performance under mesophilic and thermophilic conditions. Renew. Energ. 2018;125:915-925.

37. Hobson PN, Shaw BG. Inhibition of methane production by Methanobacterium formicicum. Water Res. 1976;10:849-852.

38. El-Gohary FA, Kamel G. Characterization and biological treatment of pre-treated landfill leachate. Ecol. Eng. 2016;94:268-274.

39. Escudié R, Conte T, Steyer JP, Delgenès JP. Hydrodynamic and biokinetic models of an anaerobic fixed-bed reactor. Process Biochem. 2005;40:2311-2323.

40. Kargi F, Pamukoglu MY. Aerobic biological treatment of pre-treated landfill leachate by fed-batch operation. Enzyme Microb. Technol. 2003;33:588-595.

41. Vidal J, Huiliñir C, Salazar R. Removal of organic matter contained in slaughterhouse wastewater using a combination of anaerobic digestion and solar photoelectro-Fenton processes. Electrochim. Acta 2016;210:163-170.

42. Lefebvre O, Moletta R. Treatment of organic pollution in industrial saline wastewater: A literature review. Water Res. 2006;40:3671-3682.

43. Rahayu S, Bata M. Quality of chicken feather processed in different conditions. Anim. Prod. 2014:16:170-175.

44. Liu C, Yuan X, Zeng G, Li W, Li J. Prediction of methane yield at optimum $\mathrm{pH}$ for anaerobic digestion of organic fraction of municipal solid waste. Bioresour. Technol. 2008;99:882-888.

45. Zolfaghari M, Jardak K, Drogui P, Brar SK, Buelna G, Dube R. Landfill leachate treatment by sequential membrane bioreactor and electro-oxidation processes. J. Environ. Manage. 2016;184:318-326.

46. Xie Z, Wang Z, Wang Q, Zhu C, Wu Z. An anaerobic dynamic membrane bioreactor (AnDMBR) for landfill leachate treatment: Performance and microbial community identification. Bioresour. Technol. 2014;161:29-39.

47. Mlaik N, Bouzid J, Belbahri L, Woodward S, Mechichi T. Combined biological processing and microfiltration in the treatment of unhairing wastewater. Environ. Sci. Pollut. Res. 2012;19:226-234.

48. Yasuhara A, Shiraishi H, Nishikawa M, et al. Determination of organic components in leachates from hazardous waste disposal sites in Japan by gas chromatography-mass spectrometry. J. Chromatogr. A. 1997;774:321-332. 